\title{
PROBABILISTIC RAINFALL THRESHOLDS FOR SHALLOW LANDSLIDES INITIATION - A CASE STUDY FROM THE NILGIRIS DISTRICT, WESTERN GHATS, INDIA
}

\author{
Edison Thennavan ${ }^{1}$, Ganapathy Pattukandan Ganapathy ${ }^{2 *}$, \\ Chandrasekaran S S ${ }^{3}$ and Ajay S Rajawat ${ }^{4}$ \\ ${ }^{1,2}$ Centre for Disaster Mitigation and Management, Vellore Institute of Technology, \\ Vellore 632014, Tamil Nadu, India \\ ${ }^{3}$ School of Civil Engineering, Vellore Institute of Technology, Vellore 632014, \\ Tamil Nadu, India \\ ${ }^{4}$ Space Application Centre (SAC), Indian Space Research Organisation, Ahmedabad 380015, \\ Gujarat, India \\ Correspondence: seismogans@yahoo.com \\ Received: 29 July; Accepted: 25 August; Published: 10 September
}

\begin{abstract}
Rainfall is one of the major causes of landslides/landslips across the globe. The fatalities and damage caused by rainfall induced landslides increased in recent days. The Nilgiris district in Western Ghats part of Tamil Nadu state is one of the very high to severe landslide hazard prone areas of India. The present study is focused on estimation of rainfall thresholds and temporal probability of landslides in different landslide prone slopes in part of The Nilgiris district. The landslide prone areas identified in earlier research are used for the present study. The landslide locations data for the years 1824 to 2018 were collected and a spatial database on landslide inventory was created. A detailed inventory carried out on the 2009 landslides were analysed and used for the calculation of rainfall thresholds. Monthly and Yearly Rainfall data for the years 2000 to 2011 were collected for 37 rainguage stations from various government agencies. Based on the quality and quantity of data, the rainfall thresholds for 14 different locations were estimated viz., Aderly, Coonoor, Coonoor Railway, Governor Sola, Ooty (Near Botanical Garden), Runnymedu, Burliar where the probability of landslide occurrences is high. The temporal probability of landslide was calculated for four years viz., 1, 3, 5 and 10 years. The present study can be used as a key to develop an early warning system in The Nilgiris District.
\end{abstract}

Key Words: Landslide, Rainfall, Threshold, Probability, Western Ghats, The Nilgiris 


\section{Introduction}

Knowing the duration, intensity and amount of precipitation triggering landslides is of great importance for landslide risk management. Global, regional and local studies carried out by the researchers revealed that the rainfall-induced landslides occur after rainfall exceeding a certain threshold value. The rainfall threshold is the minimum intensity or duration of rainfall required to initiate the landslide and it can be estimated by different empirical methods (Jaiswal and Van Westen 2009). Shallow landslides usually involve a small volume of earth and/or rubble, but they are distinguished by high speed and high energy from impact. Furthermore, during intense rainstorms many shallow landslides initiate almost simultaneously (Giannechini et al. 2012). The rainfall frequency atlas of the United States for durations from 30 minutes to 24 hours and return periods from 1 to 100 years successfully used for landslide studies by Hershfield (1961). Many researchers established relationship between rainfall and landslides (Bran et al. 1984; Pasuto and Silvano, 1998; Chleborad 2003; Aleotti 2004; Dahal RK, Hasegawa S, 2008; Guzzetti et al. 2008; Papa et al. 2013; Tien et al. 2013; Mathew et al. 2014; Segoni et al. 2014 and 2015; Dixit and Satyam 2018; Segoni et al. 2018).

Crozier (1999) used antecedent water status model to predict rainfall induced landslides. Coe et al. (2000) used historic records to identify the recurrence intervals, and exceedance probabilities of Seattle, Washington region. Glazier et al. (2009) applied probability determination to refine landslide-triggering rainfall thresholds using an empirical antecedent daily rainfall model. Squarzoni et al. (2003) carried out spatial and temporal probability by using SAR interferometry. Probabilistic forecasting of shallow rainfall-triggered landslides using real-time numerical weather predictions was tested by Schmidt (2008). Jaiswal and Van Westen (2009) carried out a study on temporal probability of landslides in transport corridors. Segoni (2009) established a definition of a real-time forecasting network for rainfall induced shallow landslides. A distributed hydrological-geotechnical model using satellite-derived rainfall estimates for shallow landslide prediction system at a catchment scale was carried out by Apip et al. (2010). Baum et al. (2010) successfully estimated the timing and location of shallow rainfall-induced landslides by using a model for transient unsaturated infiltration. Temporal probability analysis of landslides triggered by intense rainfall in the Bamenda Mountain Region, Cameroon was carried out by Afungang and Bateria (2016). Dixit and Satyam (2019) carried out study on estimation and validation using monitoring system by Probabilistic rainfall thresholds in Chibo, India.

India is one among the countries prone to rainfall-induced landslides. The landslide hazard zonation atlas of India shows that many part of India is prone for very high to severe landslide hazard (BMTPC 2003; Bhandari 2006; Rajarathnam and Ganapathy 2006). Some of the densely populated areas fall under these hazardous zones. The Nilgiris district has a history of many landslides which has generated more damage to property and infrastructure however the loss of life is less when compared to the number of landslides (Ganapathy and Hada 2012; Ganapathy and Rajawat 2015). In the recent times causalities and damages due to landslides have increased in the Nilgiri Hills (Nilgiris 2015 and The Hindu 2009). Many researchers carried out studies on landslide susceptibility and hazard mapping; however not much work reported on rainfall thresholds and temporal probability of landslides in The Nilgiris District. The objectives of the present study are to develop Rainfall Thresholds for different landslide prone areas and to estimate the temporal probability of landslides in part of the The Nilgiris District of Western Ghats, India 


\section{Study Area and its Site Characteristics}

The study area covers a stretch of $80 \mathrm{Km}$ from Hillgrove Station to Gudalur city, part of The Nilgiris district in the Western Ghats hill ranges of State Tamil Nadu, India (Fig.1). The district has an area of 2552.50Sq.km with a population of 0.735 million as per the Census of India 2011 and the district head quarter is Ooty (Udhagamandalam). The elevation varies from 1000 to $2633 \mathrm{~m}$ above mean sea level. The highest peak is in the district is Doddabetta with a height of $2,663 \mathrm{~m}$. The topography of the district is undulating with steep escarpment and about $60 \%$ of the cultivable land slopes ranging from 16 to 30 degree slope. The Nilgiri district is underlain entirely by Achaean Crystalline formations with recent alluvial and colluvial deposits (GSI 2000).

Landslide Hazard Zonation Atlas of India classified the Nilgiris district as high to severe landslide prone areas. The Study area also falls under severe landslide prone areas. The landslide activity in the district is almost seasonal during every year (Seshagiri et al. 1982). The months of October \& November are prone to landslides. The years 1902, 1978, 1979, 1993, 2001, 2006 and 2009 are notable years for landslides in the history of The Nilgiris district. In November 1891 heavy rain caused many landslips on the Coonoor Ghat, and created more damage to the Kotagiri - Metuppalayam road (Ganapathy and Rajawat 2015). Recently, in the Nilgiri Hills, casualties and damage caused by landslides have increased (Thanavelu and Chandrasekaran 2008; Chandrasekaran et al. 2013). In 2009, heavy rains triggered a series of landslides in The Nilgiris regions of Ooty, Coonoor and Kotagiri. On $10^{\text {th }}$ November 2009, 42 people died within 48 hours (Thennavan and Ganapathy 2020). The details of landslide/landslip occurrences in different corridors during the year 2009 are listed in Table 1. The district receives rainfall both during southwest and northeast monsoons. The southwest monsoon is more active contributing nearly 50 percent in the west and 40 percent in the east. The northeast monsoon is moderate, contributing nearly 40 percent. The intensity of rainfall gradually decreases from west to east. The rains during the winter and summer periods are significant. The minimum and maximum annual rainfall varies from $750 \mathrm{~mm}$ to more than $3000 \mathrm{~mm}$ and the number of rainy days varies depending on the season and the area (CGWB 2008). Since most of the landslides in the district are triggered by rainfall, a study is carried out to establish the rainfall thresholds for the different slopes and to analyse the temporal probability of annual exceedance of the landslides between Hillgrove to Gudalur stretch of The Nilgiris District.

\section{Approach}

The present study focuses on estimating rainfall thresholds and temporal probability analysis of annual exceedance of the landslides in the study area. To identify the vulnerable slopes, landslide hazard map prepared by Geological Survey of India (Seshagiri et al. 1982) is revised by using additional information like latest landslide location, Size, Volume of material involved, built area near the landslide, fatalities, reactivation etc. A detailed landslide inventory data collected from various sources as well as by limited field investigations is used in GIS platform to locate the vulnerable slopes. Based on the analysis, 18 landslide hot spots were considered (Fig. 2) as most vulnerable locations in the study area, however the details of rainguage stations were not available for all the locations to fix the rain fall thresholds. Based on the availability of the data, 14 vulnerable locations are selected for the present study (Fig. 3). Monthly Rainfall Data were collected for 52 years for the study area from India Meteorological Department (IMD) to analyse the rainfall pattern. Monthly Station wise rainfall data 
were collected for the year 2001 to 2011 from Revenue Department, Government of Tamil Nadu and daily hourly rainfall data (for $1^{\text {st }}$ to $30^{\text {th }}$ November 2009) were collected for the present study.

\section{Rainfall Thresholds}

Many researchers carried out studies and compared the empirical relationship between rainfall duration, rainfall intensity and slope instability. Estimation of rainfall thresholds is an important parameter for landslide warning systems (Clark 1987; Jibson 1989; Keefer et al. 1987; Neary and Swift 1987; Wilson and Wieczorek 1995). Caine (1980) suggests a general threshold that works for time periods between 10 minutes and 10 days for 73 events in different geologic and climatic conditions. On the other hand, empirical models are obtained by analyzing the rainfall events which resulted in landslides. Such kinds of studies measure the severity and length of the rainfall resulting in landslides using statistical data and obtain a threshold value. The relationship of this threshold value is generally obtained by drawing lower bound lines to the conditions of rainfall which resulted in landslides in cartesian, semi-ogarithmic or logarithmic co- ordinates (Guzzetti et al. 2007). Researchers carried out study on automatic calculation of rainfall thresholds for landslide studies (Melillo et al. 2018; Gariano et al. 2019).

\subsection{Temporal probability assessment}

The time series of daily rainfall $\mathrm{R}_{\mathrm{d}}(\mathrm{t})$ in $\mathrm{mm}$ day- 1 , where $\mathrm{t}$ is time. For a landslide $(\mathrm{L})$ to occur, the daily rainfall must exceed a threshold, which is a function $\mathrm{R}(\mathrm{t})$ of the daily rainfall in a period, and of the amount of the antecedent rainfall $\mathrm{R}_{\mathrm{ad}}(\mathrm{t})$, i.e., rainfall that have occurred prior to the day of landslide occurrence (Jaiswal and Van Westen 2009; ITC Netherland 2013).

$$
\mathrm{R}(\mathrm{t})=f\left(\operatorname{Rd}(\mathrm{t}), \mathrm{R}_{\mathrm{ad}}(\mathrm{t})\right)
$$

Where $\mathrm{R}_{\mathrm{ad}}(\mathrm{t})$ is the antecedent rainfall in $\mathrm{mm}$. This function of $\mathrm{R}$ defines the probability of occurrence of the landslide $\mathrm{L}: \mathrm{P}(\mathrm{L})$. If $\mathrm{R}_{\mathrm{T}}$ is the threshold value of $\mathrm{R}$ then,

$$
\mathrm{P}(\mathrm{L} \mid(\mathrm{R}>\mathrm{RT}))=1 \text { and } \mathrm{P}(\mathrm{L} \mid(\mathrm{R} \leq \mathrm{RT}))=0
$$

Thus, in this simplified model, landslides always occur when $\mathrm{R}$ exceeds $\mathrm{R}_{\mathrm{T}}$ and does not occur when value of $\mathrm{R}$ is lower than or equal to $\mathrm{R}_{\mathrm{T}}$. In the previous case, the likelihood of occurrences of landslide $\mathrm{P}(\mathrm{L})$ depends on the exceedance probability of $\mathrm{P}(\mathrm{R}>\mathrm{RT})$, i.e., $\mathrm{P}(\mathrm{L})$ $=\mathrm{P}(\mathrm{R}>\mathrm{RT})$.

Thus, the probability of landslide occurrences can be given by the intersection of two probabilities,

$$
\mathrm{P}((\mathrm{R}>\mathrm{RT}) \mid \mathrm{L})=\mathrm{P}(\mathrm{R}>\mathrm{RT}) \times \mathrm{P}(\mathrm{L} \mid(\mathrm{R}>\mathrm{RT}))
$$




\subsection{Estimating Rainfall threshold for a given day}

The Rainfall threshold can be estimated from the daily rainfall data which is collected from the rainguage. The methodology used by Jaiswal and Van Westen 2009 and ITC Netherland 2013 are used for the present study. Daily hourly data from particular rainguage station closer to the different dates of landslide location were considered in the same month. The 5-Days Antecedent (5-AD) rainfall for each year from daily rainfall of landslide events calculated (for 5 -days AD, add the previous 5 days of daily rainfall). For Example, the 5-AD for November $6^{\text {th }}$ will be sum of daily rainfall of November $5^{\text {th }}$ to November $1^{\text {st. Then the daily }}$ rainfall and the corresponding 5-AD rainfall for the all the landslide event in the same period will be plotted. A line drawn manually such that it demarcates the lower end of the plotted points and extend it up to the $\mathrm{x}$ and $\mathrm{y}$ axis. The line is a straight line with negative slope of the type $y=-m x+c$, where $m$ is the slope and $c$ is the intercept. The equation computed for the line for example $m=y 2-y 1 / x 2-x 1$. For this line the equation can be written as $R T=K-p^{*} R_{5 a d}$. Here $\mathrm{K}, \mathrm{p}$ are constants. $\mathrm{RT}=$ Rainfall Threshold. $\mathrm{R}_{5 \mathrm{ad}}=$ Rainfall 5 Day Antecedents. Using this equation the rainfall Thresholds are calculated for the 14 different locations viz. Adarly, Coonoor, Coonoor_Rly, Governersola, Gudalur, Currency, Hillgroove, Kethi, Naduvattam, Ooty, Ooty_scr, Runnymedu, Valvewoodest, Burliar. The K value varies from 65 to 220 in these locations. The RT graphs for the 14 locations are presented in Fig. 4 and Table 2. The threshold exceedance of a given calculated by using the daily rainfall and rainfall threshold of the day. It will be expressed as Threshold exceedance = Daily rainfall - Rainfall threshold.

\section{Annual Exceedance Probability (AEP)}

The Annual Exceedance Probability (AEP) is the estimated probability that an event of specific magnitude will be exceeded in any given year (Fell et al. 2005). For a given rain gauge Annual Exceedance Probability of the threshold P $(\mathrm{R}>\mathrm{RT})$ was determined using a Poisson probability model. Coe et al. (2000, 2004); Guzzetti et al. (2005) and Chleborad et al. (2006) successfully used a model to determine the exceedance probability of landslide in time.

$$
\mathrm{P}[\mathrm{N}(\mathrm{t}) \geq 1]=1-\exp (-\mathrm{t} / \mu)
$$

Where, $\mu$ is the mean recurrence interval between successive landslide events which can be obtained from the multi-temporal landslide inventory data. The probability prediction for 14 locations for the different return periods viz, 1, 3, 5 and 10 years were calculated and presented in Table 3 and Fig. 5. The likelihood of having one or more rainfall events that can trigger landslides in any given years varies from 0.48 to 2.60. Similar kinds of rainfall events are capable of triggering one or more landslides in the months of October to December.

\section{Conclusions}

The present study of rainfall threshold and temporal probability from Hill grove to Gudalur is carried out because of the vulnerability of slopes and its risk towards the settlement areas. Rainfall threshold were calculated for 14 sites in the district depending on the availability of rainguage network and data availability. Based on the value individual sites were assessed. The Annual Exceedance Probability calculated for 4 Years viz 1, 3, 5, and 10. Out of 14 Sites 
6 sites viz, Coonoor Railway, Governersola, Gurrency, Kethi, Naduvattam and Valvewoodest were having high probability of landslides in a year chances of 1 time if the same antecedent's rainfall occurred in the particular site. The location Hillgrove will have chances in three years once and Ooty (Scr) will have chances in five years once. Among all Valvewoodest and Kethi are the two locations more vulnerable based on the annual probability exceedance of landslides. The study has its own limitations. The rainfall data were used from various agencies (Government and Non-Government), so the calibration of instruments is not known for some of the stations. Another limitation is the availability of the rainfall data. Most of the historical period data were not available and a good record of data after 2007 only available. The date of inventory also plays a major role when it compared with rainfall occurrence and accumulation period. Generally landslides happened during rainy season and the documentation of landslide will be carried out by the agencies after few days. The dates of landslides are based on local interview. The present methodology can be applicable for other part of the district having same geo-climatic conditions. The people in the high vulnerability areas should be trained for landslide response. The present study can be used as a key for landslide early warning in the study area. Also guidelines should be prepared for assessing, planning policy and consent requirement for landslide prone lands in The Nilgiris District.

\section{References}

1. Afungang RN, Bateira CV., 2016, Temporal probability analysis of landslides triggered by intense rainfall in the Bamenda Mountain Region, Cameroon. Environmental Earth Science 75:1032-1043

2. Aleotti P., 2004, A warning system for rainfall-induced shallow failures. - Engineering Geology 73:247-265

3. Apip TK, Yamashiki Y, Sassa K, Ibrahim AB, Fukuoka H., 2010, A distributed hydrological-geotechnical model using satellite-derived rainfall estimates for shallow landslide prediction system at a catchment scale. Landslides 7:237-258

4. Baum RL, Godt JW, Savage WZ., 2010, Estimating the timing and location of shallow rainfall-induced landslides using a model for transient unsaturated infiltration. J Geophys Res 115:F03013. https://doi.org/10.1029/2009JF001321

5. Bhandari RK., 2006, The Indian Landslide Scenario, Strategic Issues and Action Points, (A Key Note address - Technical Session on Landslides) First India Disaster Management Congress, New Delhi, pp 29-30

6. BMTPC., 2003, Landslide Hazard Zonation Atlas of India, Published by Building Materials and technology Promotion Council, Government of India and Anna University, Chennai, p 125

7. Brand EW, Premchitt J. Phillipson HB., 1984, Relationship between rainfall and landslides in Hong Kong. - In: Proc. 4th Internat Symp on Landslides. Canadian Geotechnical Society, Toronto, Canada, pp 377-384

8. Caine N., 1980, The rainfall intensity-duration control of shallow landslides and debris flows. - Geogr. Ann. Series A 62:23-27

9. CGWB., 2008, District Groundwater Brochure Nilgiri District, TAMIL NADU, Technical Report Series, Government of India published by Ministry of Water Resources, Central Ground Water Board, South Eastern Coastal Region, Chennai. p 21 
10. Chandrasekaran SS, Sayed OR, Ashwin S et al., 2013, Investigation on infrastructural damages by rainfall-induced landslides during November 2009 in Nilgiris, India. Natural Hazards 65:1535-1557. https://doi.org/10.1007/s11069-012-0432-x

11. Chleborad AF., 2003, Preliminary evaluation of a precipitation threshold for anticipating the occurrence of landslides in the Seattle, Washington Area. USGS Open-file report 03-463, U.S. Geological Survey, Reston, p17

12. Chleborad AF, Baum RL, Godt JW., 2006, Rainfall thresholds for forecasting landslides in the Seattle, Washington, area-Exceedance and probability: U.S. Geological Survey OpenFile Report 2006-1064

13. Coe JA, Michael JA, Crovelli RA, Savage WZ., 2000, Preliminary map showing landslide densities, mean recurrence intervals, and exceedance probabilities as determined from historic records, Seattle, Washington: U.S. Geological Survey Open-File Report 00-xxx, in review

14. Crozier MJ.,1999, Prediction of rainfall-triggered landslides: a test of the antecedent water status model. - Earth Surface Proceedings and Landforms 24: 825-833

15. Dahal RK, Hasegawa S., 2008, Representative rainfall thresholds for landslides in the Nepal Himalaya, Geomorphology, 100(3-4):429-443. https://doi.org/10.1016/j.geomorph.2008.01.014

16. Dikshit A, Satyam DN., 2018, Estimation of rainfall thresholds for landslide occurrences in Kalimpong, India. Innovative Infrastructure Solutions, 3: 24. https://doi.org/10.1007/ s41062-018-0132-9

17. Dikshit A, Satyam N., 2019, Probabilistic rainfall thresholds in Chibo, India: estimation and validation using monitoring system. J Mountain Science, 16: 870-883

18. Earth Explorer Aster Global DEM., 2011, ASTER GDEM is a product of METI and NASA. http://earthexplorer.usgs.gov/ Accessed 02 May 2015

19. Ganapathy GP, Rajawat AS., 2015, Use of hazard and vulnerability maps for landslide planning scenarios: a case study of the Nilgiris, India, Springer - Natural Hazards, Journal of the International Society for the Prevention and Mitigation of Vol. 77, No.1, Natural Hazards 77: 305-316. https://doi.org/10.1007/s11069-015-1587-z

20. Ganapathy GP, Hada CL., 2012, Landslide Hazard Mitigation in the Nilgiris District, India - Environmental and Societal Issues, International Journal of Environmental Science and Development, 3: 5

21. Gariano SL, Sarkar R, Dikshit A, Dorji K, Brunetti MT, Peruccacci S, Melillo M ., 2019, Automatic calculation of rainfall thresholds for landslide occurrence in Chukha Dzongkhag, Bhutan. Bulletin of Engineering Geology and the Environment, 78:4325-4332

22. Giannecchini R, Galanti Y, and D'Amato Avanzi G., 2012, Critical rainfall thresholds for triggering shallow landslides in the Serchio River Valley (Tuscany, Italy), Nat Hazards Earth Syst Sci, 12:829-842

23. Glade T, Crozier M, Smith P., 2000, Applying probability determination to refine landslide-triggering rainfall thresholds using an empirical Antecedent Daily Rainfall Model. - Pure and Appl Geophysics 157:1059-1079

24. GSI., 2000, District Resource Map Series: Nilgiri District Tamil Nadu, published by Geological Survey of India-explanatory Note.

25. Guzzetti F, Reichenbach P, Cardinali M et al., 2005, Probabilistic landslide hazard assessment at the basin scale. Geophys J Roy Astron Soc 72:272-299

26. Guzzetti F, Peruccacci S, Rossi M, Stark CP., 2007, Rainfall thresholds for the initiation of landslides in central and southern Europe Meteorol Atmos Phys 98:239-267 
27. Guzzetti F, Peruccacci S, Rossi M, Stark CP., 2008, The rainfall intensity-duration control of shallow landslides and debris flows: an update. Landslides 5:3-17

28. Hershfield DM., 1961, Rainfall frequency atlas of the United States for durations from 30 minutes to 24 hours and return periods from 1 to 100 years. - Technical Paper No. 40, Washington, D. C.: National Weather Bureau, pp 15

29. Jaiswal P, Van Westen CJ., 2009, Probabilistic landslide initiation hazard assessment along a transportation corridor in the Nilgiri area, India, Geophysical Research Abstracts, Vol. 11, EGU2009-2854, EGU General Assesmbly

30. Jaiswal P, van Westen CJ., 2009, Estimating temporal probability for landslide initiation along transportation routes based on rainfall thresholds. Geomorphology, 112:96-105

31. Keefer DK, Wilson RC, Mark RK, Brabb EE, Brown WM III, Ellen SD, Harp EL, Wieczoreck GF ACS, Zatkin RS., 1987, Real-time landslide warning during heavy rainfall. Science 238:921-926

32. Mathew J, Babu DG, Kundu S, Vinod Kumar K, Pant CC., 2014, Integrating intensity-duration-based rainfall threshold and antecedent rainfall-based probability estimate towards generating early warning for rainfall-induced landslides in parts of the Garhwal Himalaya, India. Landslides 11:575-588

33. Melillo M, Brunetti MT, Peruccacci S, Gariano SL, Roccati A, Guzzetti F., 2018, A tool for the automatic calculation of rainfall thresholds for landslide occurrence. Environmental Modeling and Software 105:230-243

34. Nilgiris., 2015) http://nilgiris.nic.in/disaster.htm

35. Papa MN, Medina V, Ciervo F, Bateman A., 2013, Derivation of critical rainfall thresholds for shallow landslides as a tool for debris flow early warning systems, Hydrology and Earth System Science 17:4095-4107

36. Pasuto A, Silvano S., 1998, Rainfall as a trigger of shallow mass movements. A case study in the Dolomites, Italy. Environ Geol, 35(2-3):184-189

37. Rajarathnam S, Ganapathy GP., 2006, Landslide Hazard Zonation of India, a GIS Approach, Proceedings of the First India Disaster Management Congress, New Delhi, pp 29-30

38. Segoni S, Lagomarsino D, Fanti R, Moretti S, and Casagli N., 2014, Integration of rainfall thresholds and susceptibility maps in the Emilia Romagna (Italy) regional-scale landslide warning system, Landslides, 12:773-785. https://doi.org/10.1007/s10346-014-0502-0

39. Schmidt J, Turek G, Clark MP, Uddstrom M, Dymond JR., 2008, Probabilistic forecasting of shallow rainfall-triggered landslides using real-time numerical weather predictions. Nat Hazards Earth Syst Sci 8:349-357

40. Segoni S, Leoni L, Benedetti AI, Catani F, Righini G, Falorni G, Gabellani S, Rudari R, Silvestro F, Rebora N., 2009, Towards a definition of a real-time forecasting network for rainfall induced shallow landslides. Nat Hazard Earth Syst Sci. 9:2119-2133

41. Segoni S, Rossi G, Rosi A, Catani F., 2014, Landslides triggered by rainfall: a semi-automated procedure to define consistent intensity-duration thresholds. Computer Geoscience 63:123-131

42. Segoni S, Lagomarsino D, Fanti R, Moretti S, Casagli N., 2015, Integration of rainfall thresholds and susceptibility maps in the Emilia Romagna (Italy) regional-scale landslide warning system. Landslides 12:773-785

43. Segoni S, Piciullo L, Gariano SL., 2018, A review of the recent literature on rainfall thresholds for landslide occurrence. Landslides, 15:1483-1501 
44. Segoni S, Rossi G, Rosi A, Catani F., 2014, Landslides triggered by rainfall: a semi-automated procedure to define consistent intensity-duration thresholds. Computers and Geosciences 63:123-131

45. Seshagiri DN, Badrinarayanan S, Upendran R et al., 1982, The Nilgiris landslide - Miscellaneous publication No. 57. Geological Survey of India

46. Squarzoni C, Delacourt C, Allemand P., 2003, Nine years of spatial and temporal evolution of the La Vallette landslide observed by SAR interferometry. J Engineering Geology 68:53-66

47. Thanavelu C, Chandrasekaran., 2008, Geotechnical Assessment of November 2006 landslides in the Nilgiris Tamil Nadu, Abstract Volume: Proceedings of the National Seminar on Challenges in Engineering Geology, 03rd to 05th December 2008, Hyderabad

48. The Hindu., 2009, Scale of damage in Nilgiris huge, relief work space, http://www.thehindu.com/2009/11/12/stories/2009111258110100.htm. Accessed 12 November 2009

49. Thennavan E, Ganapathy GP., 2020, Evaluation of landslide hazard and its impacts on hilly environment of the Nilgiris District - a geospatial approach. Geoenviron Disasters 7, 3. https://doi.org/10.1186/s40677-019-0139-3

50. Tien Bui D, Pradhan B, Lofman O, Revhaug I, Dick OB., 2013, Regional prediction of landslide hazard using probability analysis of intense rainfall in the Hoa Binh province, Vietnam. Natural Hazards 66:707-730

51. Wilson RC, Wieczorek GF., 1995, Rainfall thresholds for the initiation of debris flow at La Honda, California. - Environm and Engin Geoscience 1(1):11-27.

\section{List of Tables}

Table 1. Landslide incidences in different corridors in The Nilgiris districts during the Year 2009

Table 2. Calculated threshold values for different sites in the study area

Table 3. Probability Prediction of location wise landslide probability

\section{List of Figures}

Fig. 1 Study area and its Landslide Hazard Severity

Fig. 2 Revised Landslide Hazard impact areas considered for the study

Fig. 3 Selected Locations for Rainfall Threshold Calculations within the buffer zone of rainguage stations

Fig. 4 Estimated rainfall thresholds for 14 different locations in the study area

Fig. 5 Annual Probability of Landslides (percentage of exceedance for 1, 3, 5 and 10 Years) 
Table 1. Landslide incidences in different corridors in The Nilgiris districts during the Year 2009

\section{Sl.No Road Corridors}

Number of Landslides/Slips

1 As reported from petitions received from public 91

2 NH 67 - (Mettupalayam - Coonoor- Ooty) 160

3 Other District roads Municipalities, Town Panchayats and Village Panchayats 544

4 Ketty - Palada Seles Road 26

5 Kattabetta - Iduhatty Road 26

6 Coonoor - Kattabetta Road 33

7 Kundah Begumbella Road 39

8 Coonoor - Kundah Road 50

9 Ooty Avalanchi Kundah Thai Sola Road 59

10 Ooty - Kotagiri - Mettupalayam Road 122

Table 2. Calculated threshold values for different sites in the study area

\begin{tabular}{cll}
\hline Sl. No. & Raingauge Name / Location & Threshold \\
\hline 1 & Adarly & $\mathrm{RT}=130-0.79^{*} \mathrm{R}_{5 \mathrm{AD}}$ \\
2 & Coonoor & $\mathrm{RT}=90-0.86^{*} \mathrm{R}_{5 \mathrm{AD}}$ \\
3 & Coonoor_rly & $\mathrm{RT}=100-0.67^{*} \mathrm{R}_{5 \mathrm{AD}}$ \\
4 & Governersola & $\mathrm{RT}=75-0.63^{*} \mathrm{R}_{5 \mathrm{AD}}$ \\
5 & Gudalur & $\mathrm{RT}=135-1.7^{*} \mathrm{R}_{5 \mathrm{AD}}$ \\
6 & Currency & $\mathrm{RT}=89-0.64^{*} \mathrm{R}_{5 \mathrm{AD}}$ \\
7 & Hillgroove & $\mathrm{RT}=110-1.1^{*} \mathrm{R}_{5 \mathrm{AD}}$ \\
8 & Kethi & $\mathrm{RT}=120-0.8^{*} \mathrm{R}_{5 \mathrm{AD}}$ \\
9 & Naduvattam & $\mathrm{RT}=65-0.45^{*} \mathrm{R}_{5 \mathrm{AD}}$ \\
10 & Ooty & $\mathrm{RT}=150-0.83^{*} \mathrm{R}_{5 \mathrm{AD}}$ \\
11 & Ooty_scr & $\mathrm{RT}=66-0.69^{*} \mathrm{R}_{5 \mathrm{AD}}$ \\
12 & Runnymedu & $\mathrm{RT}=180-0.93^{*} \mathrm{R}_{5 \mathrm{AD}}$ \\
13 & Valvewoodest & $\mathrm{RT}=102-0.82^{*} \mathrm{R}_{5 \mathrm{AD}}$ \\
14 & Burliar & $\mathrm{RT}=220-0.61^{*} \mathrm{R}_{5 \mathrm{AD}}$ \\
\hline
\end{tabular}


Table 3. Probability Prediction of location wise landslide probability

\begin{tabular}{llcccc}
\hline \multirow{2}{*}{ Sl.No } & \multicolumn{1}{c}{ Location } & $\mathbf{1}$ & $\mathbf{3}$ & $\mathbf{5}$ & $\mathbf{1 0}$ \\
\hline 1 & Adarly & 0.70 & 0.75 & 0.75 & 0.73 \\
2 & Coonoor & 0.48 & 0.48 & 0.48 & 0.48 \\
3 & Coonoor Railway & 1.60 & 1.90 & 1.91 & 1.91 \\
4 & Governersola & 1.28 & 1.80 & 1.85 & 1.86 \\
5 & Gudalur & 0.79 & 0.91 & 0.92 & 0.92 \\
6 & Gurrency & 1.47 & 2.22 & 2.32 & 2.33 \\
7 & Hillgroove & 0.89 & 1.00 & 1.00 & 1.00 \\
8 & Kethi & 1.38 & 1.76 & 1.78 & 1.78 \\
9 & Naduvattam & 1.22 & 2.16 & 2.41 & 2.50 \\
10 & Ooty & 0.48 & 0.48 & 0.48 & 0.48 \\
11 & Ooty (Scr) & 0.81 & 0.99 & 1.00 & 1.00 \\
12 & Runnymedu & 0.28 & 0.37 & 0.38 & 0.38 \\
13 & Valvewoodest & 1.47 & 2.39 & 2.56 & 2.60 \\
14 & Burliyar & 0.46 & 0.70 & 0.73 & 0.73 \\
\hline
\end{tabular}

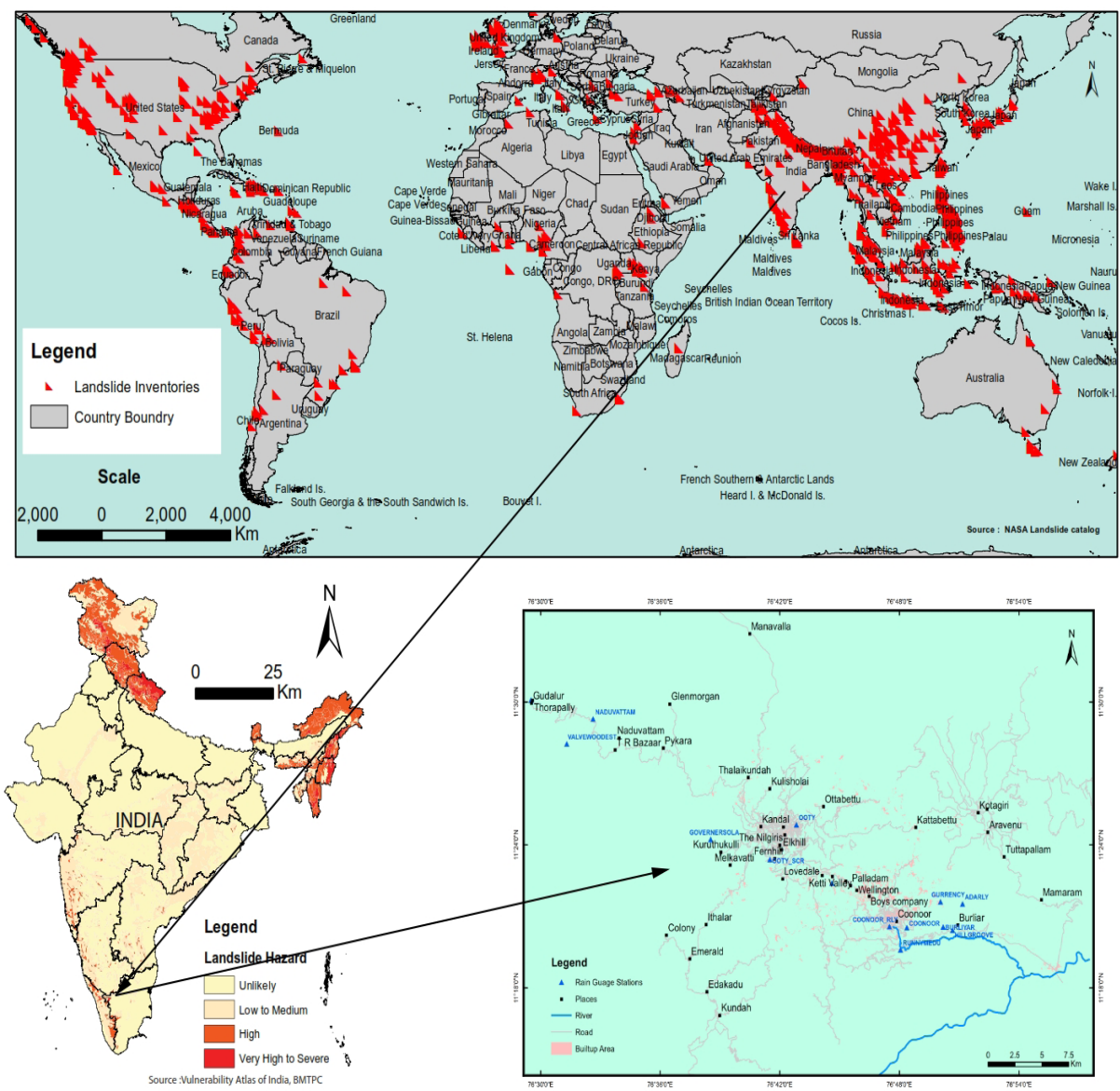

Fig. 1 Study area and its Landslide Hazard Severity 




Fig. 2 Revised Landslide Hazard impact areas considered for the study

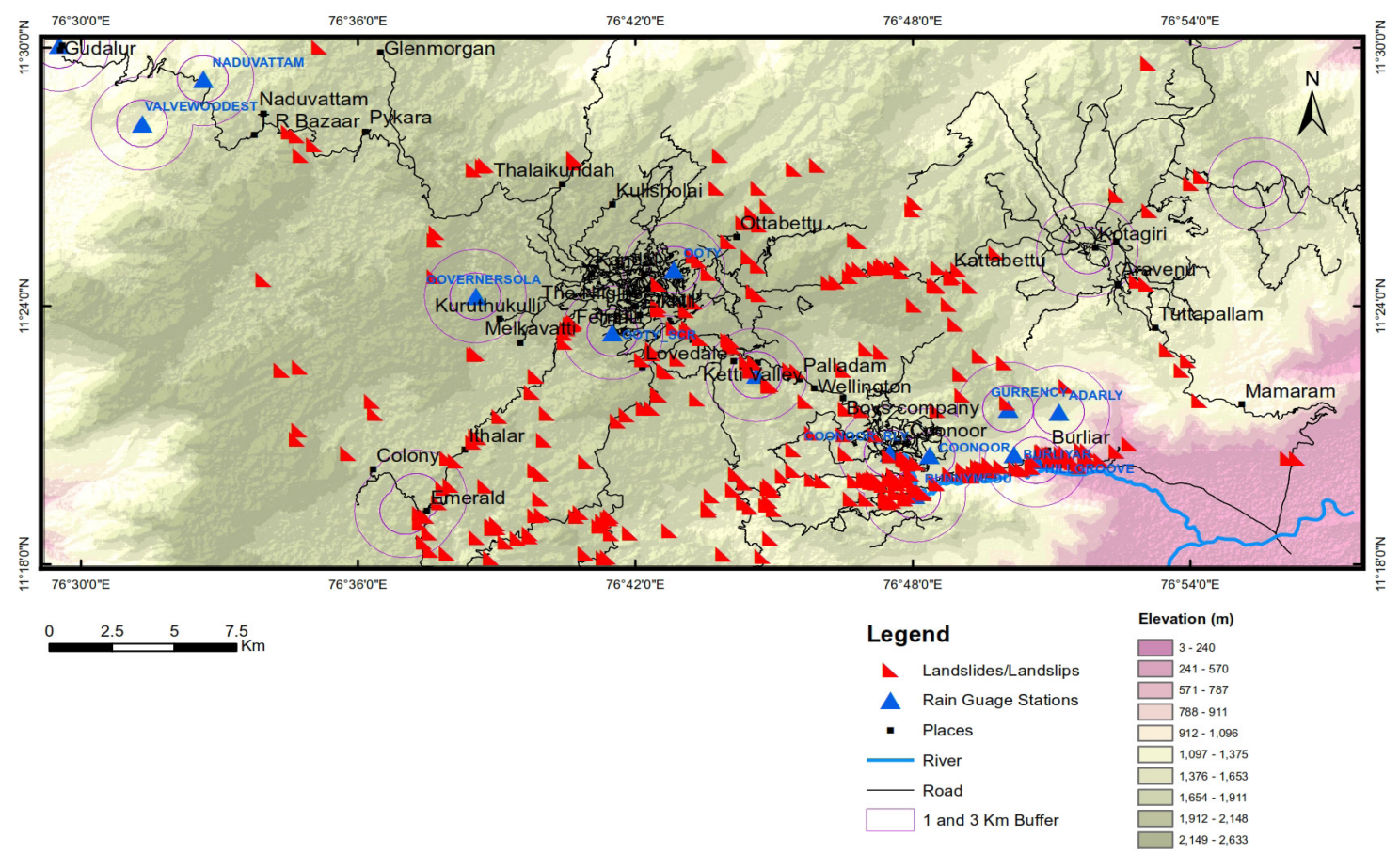

Fig. 3 Selected Locations for Rainfall Threshold Calculations within the buffer zone of rainguage stations 


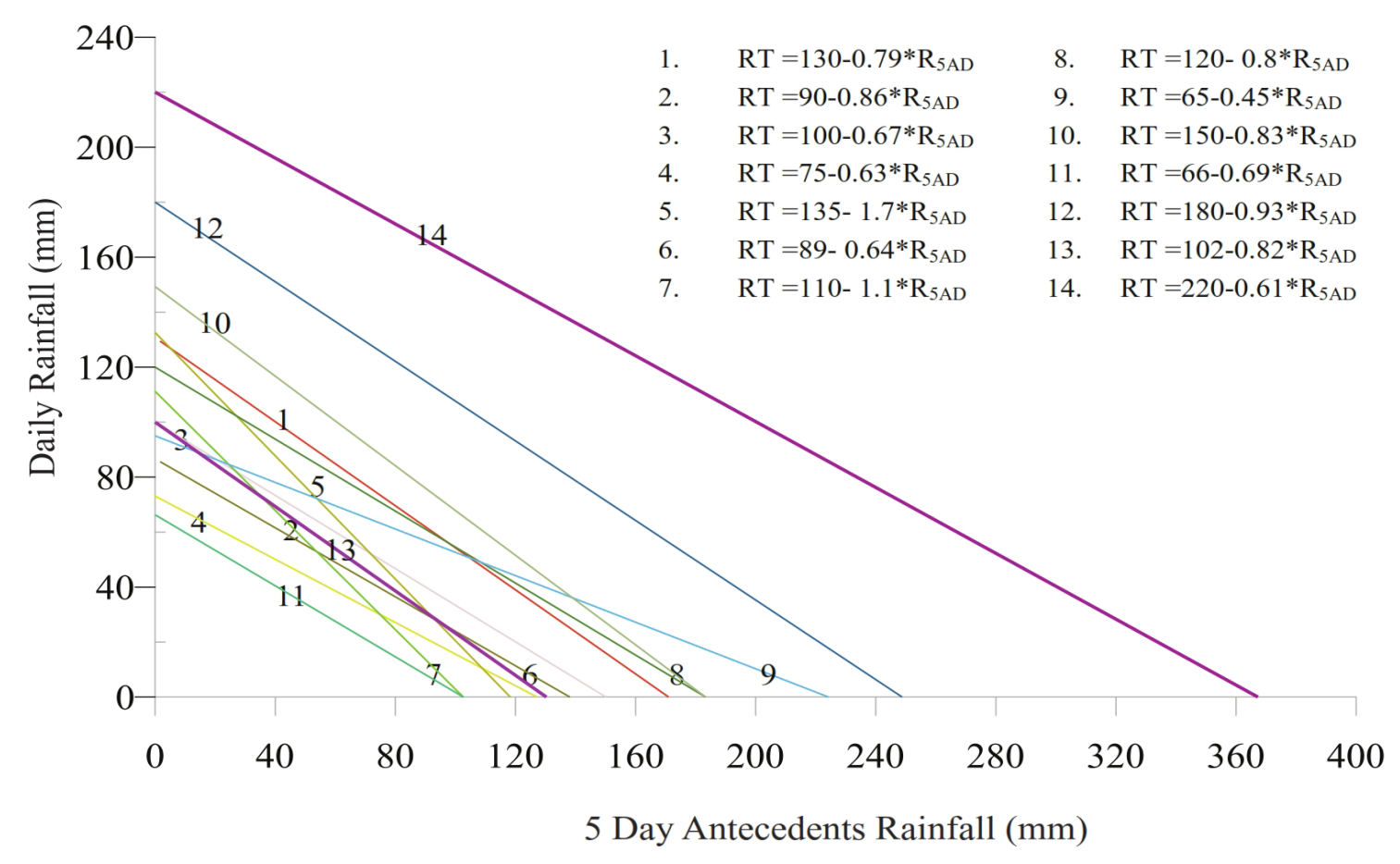

Fig. 4 Estimated rainfall thresholds for 14 different locations in the study area
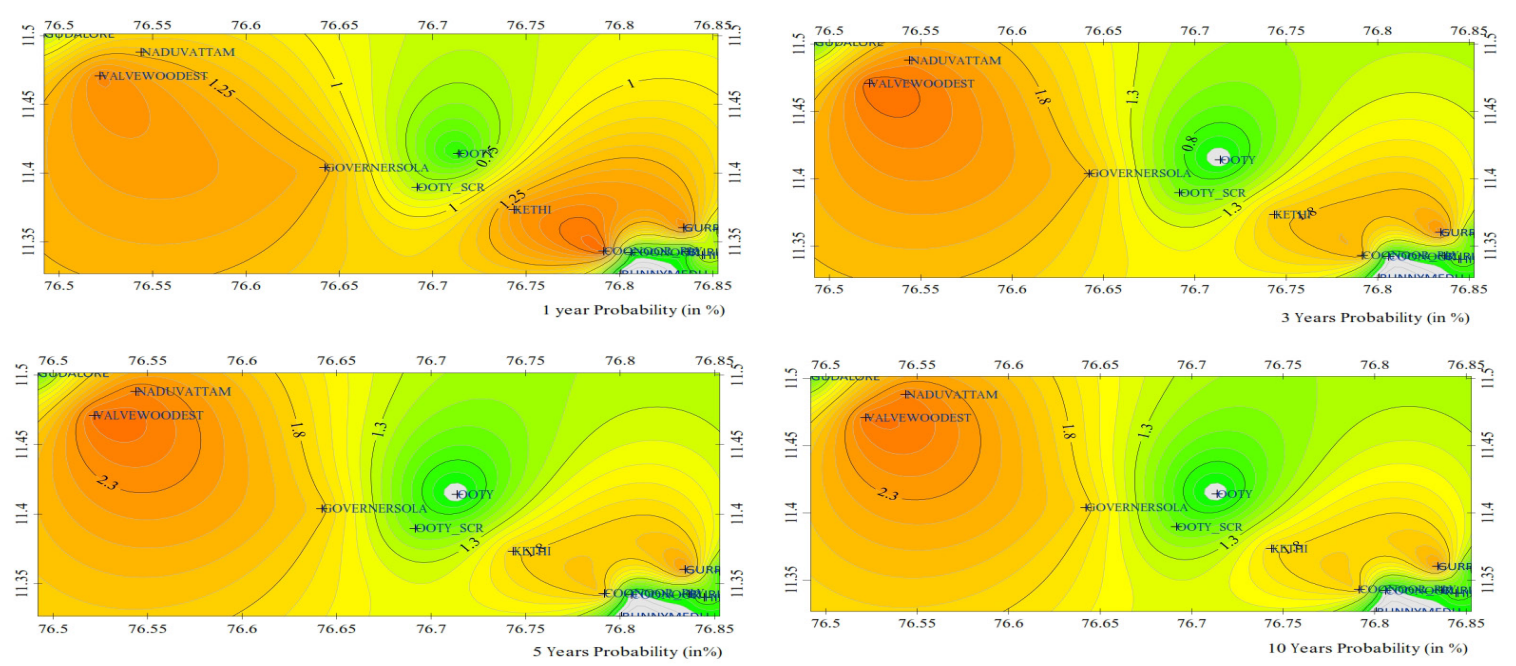

Fig. 5 Annual Probability of Landslides (percentage of exceedance for 1, 3, 5 and 10 Years) 
